\title{
Evaluation of the Kinect controller precision
}

\section{Ocena precyzji działania kontrolera Kinect}

\author{
Piotr Mieszawski*, Tomasz Szymczyk \\ Department of Computer Science, Lublin University of Technology, Nadbystrzycka 36B, 20-618 Lublin, Poland
}

\begin{abstract}
The subject of this work is to evaluate the precision of the Kinect controller operation. Research study was performed and a measuring stand have been prepared. Then an application was created that captures the user's throw gesture and simulates the flight of a virtual ball. Based on this, measurements were made to determine the difference between hand movement and it's detection by the application, and differences among throw made in real life and in VR. The analysis of these results allowed the accuracy of the controller to be assessed.
\end{abstract}

Keywords: comparative analysis; Kinect; virtual reality

\section{Streszczenie}

Tematem tej pracy jest ocena precyzji działania kontrolera Kinect. Na potrzeby tego został opracowana metodyka badawcza oraz przygotowane stanowisko pomiarowe. Następnie została stworzona aplikacja, która wychwytuje gest rzutu użytkownika oraz symuluje lot wirtualnej piłki. Na podstawie tego wykonano pomiary, polegające na określeniu różnicy kątów pomiędzy tym jak poruszała się dłoń, a jak to zostało wykryte przez aplikacje oraz określeniu różnicy pomiędzy odległością rzutu wykonanego w rzeczywistości a w VR (ang. Virtual Reality). Analiza tych wyników pozwoliła określić precyzje kontrolera.

Słowa kluczowe: Kinect; wirtualna rzeczywistość; analiza porównawcza

${ }^{*}$ Corresponding author

Email address: piotr.mieszawski@pollub.edu.pl

(CPublished under Creative Common License (CC BY-SA v4.0)

\section{Wstęp}

Wirtualna rzeczywistość aktualnie jest znana jako sztuczny, trójwymiarowy obraz wytworzony przy wykorzystaniu najnowszej technologii. Może zawierać w sobie różnego rodzaju przedmioty, obiekty a nawet całe zdarzenia. Może się opierać zarówno na elementach świata fikcyjnego jak i realnego.

Założeniami tej technologii jest wywołanie u ludzi prawdziwych i naturalnych odczuć. Nie jest to łatwe, ponieważ ludzki mózg jest tak skonstruowany, że na podstawie najmniejszych detali może wyczuć, że widziany obraz nie jest prawdziwy. Dlatego aby stworzyć świat wirtualny jak najbardziej przypominający realny trzeba zrozumieć fizjonomie człowieka. Każdy element jest poznawany za pomocą zmysłów. $Z$ tego powodu trzeba było wykorzystać możliwości, które pozwoliłyby je oszukać. Jednym z najpopularniejszych takich rozwiązań, są okulary VR, które odcinają użytkownika od prawdziwego świata i pokazują tylko ten wirtualny. Dodatkowo trzeba było odpowiednio oddać dźwięki otoczenia, tak aby odczucia wzorkowe i słuchowe były spójne. Aby poruszać się w takim świecie, potrzebny jest także kontroler. Istnieje aktualnie wiele rozwiązań, gdzie jednymi z najpopularniejszych są VR joystick'i, które trzymane w dłoniach przekazują ich położenie do VR. Jednak jeszcze inne możliwości tworzą interfejsy bezdotykowe. Takim przykładem jest Kinect od firmy Microsoft. Wykorzystuje on zestaw czujników oraz kamer, aby w przestrzeni 3D przenieść ruchy ciała do wirtualnej rzeczywistości. Wtedy kontrolerem staje się sam użytkownik. W tej pracy zostały przeprowadzone badania jak precyzyjnie działają takie kontrolery. Do tego został wykorzystany bezdotykowy interfejs Kinect $360[1,2]$.

\section{Opis badania}

$\mathrm{Na}$ potrzeby artykułu zostało stworzone oprogramowanie pozwalające na zbadanie precyzji działania kontrolera Kinect. Zostało ono wykorzystane do wykonania dwóch badań.

Pierwszym z nich było sprawdzenie, jak dokładnie wychwytywany jest kąt prowadzenia ręki oraz czy jest różnica $\mathrm{w}$ wynikach $\mathrm{w}$ zależności od ustawienia użytkownika względem Kinect'a. Biorąc pod uwagę, że zasięg działania czujników, który wynosi od $0,8 \mathrm{~m}$ do 4,5 m badanie zostało przeprowadzone na dystansie 2,5 m. Dodatkowo wykonano je z trzech punktów oddalonych od siebie o $1 \mathrm{~m}$. Miejsca rozmieszczenia stanowisk zostały pokazane na rysunku 1 .

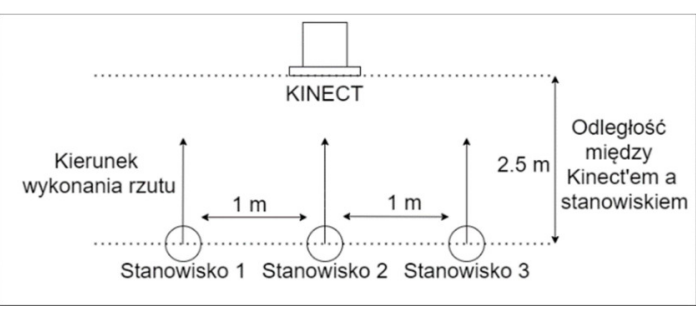

Rysunek 1: Poglądowe miejsca stanowisk wykonania rzutu, podczas badania pierwszego.

Były badane kąty 30 i 45 stopni. W celu jak najdokładniejszego ich oddania, została wykorzystana linka, 
ustawiona pod wybranym kątem. Dzięki temu rozwiązaniu ręka poruszając się wzdłuż niej wykonywała ruch pod kątem jak najbardziej zbliżonym do badanego.

Kolejnym badaniem było porównanie odległości uzyskanych po wykonaniu rzutów w rzeczywistości oraz wykonując gest przed Kinect'em. Do rzutu rzeczywistego wykorzystano piłkę tenisową o wadze $60 \mathrm{~g}$ oraz średnicy $6,5 \mathrm{~cm}$. Ten rzut był wykonany na świeżym powietrzu w warunkach możliwie bezwietrznych, aby jak najbardziej ograniczyć wpływ warunków atmosferycznych na wyniki. Z kolei rzut w VR został wykonany tak, aby osoba badana widziała zachowanie piłki przed rzutem oraz tor lotu piłki po wykonaniu odpowiedniego gestu. $\mathrm{Na}$ rysunku 2 została pokazana plansza, która została stworzona na potrzeby aplikacji.

\section{Implementacja aplikacji}

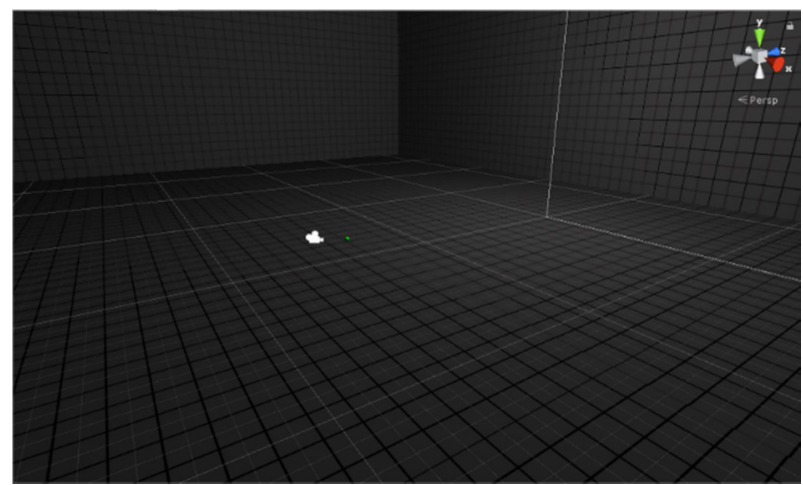

Rysunek 2: Stworzone środowisko w wirtualnej rzeczywistości.

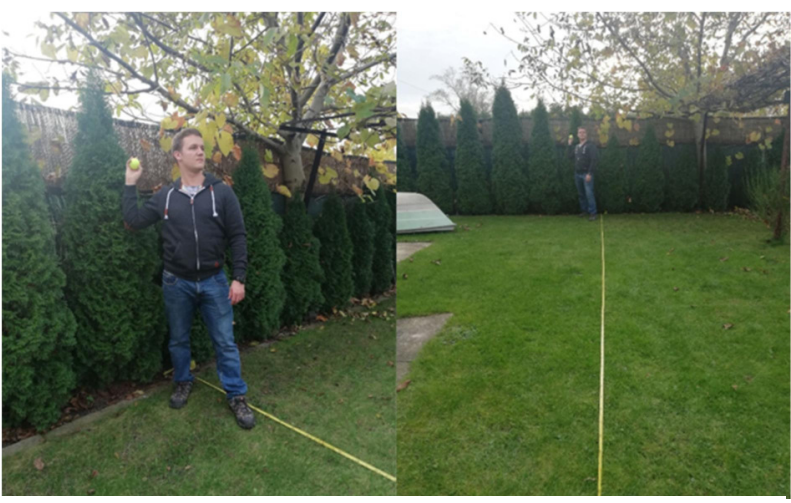

Rysunek 3: Miejsce badawcze z którego zostały wykonywane rzuty do badania nr 2 .

Aplikacja została napisana w języku C\# przy użyciu środowiska Unity [3,4]. Zastosowano bibliotekę Kinect with MS-SDK, która zawiera w sobie narzędzia, które znacząco przyśpieszyły tworzenie aplikacji [5]. Kinect sprawdza położenie 20 punktów ciała $\mathrm{z}$ częstotliwością 30 razy na sekundę [6]. Algorytm, aby wyliczyć moment rzutu, bierze pod uwagę tylko miejsce położenia prawej dłoni. Gest rzutu został podzielony na 4 fazy:

- W pierwszej fazie jest sprawdzane, czy ręka jest na odpowiedniej wysokości względem reszty ciała.

- W drugiej fazie, ręka jest w ruchu, wykonując gest rzutu. Wtedy na podstawie położenie ręki obliczana jest prędkość oraz kąt z jakimi porusza się ręka.
- W trzeciej fazie, ręka zatrzymuje się i Kinect wyłapuje moment, kiedy prędkość była największa. Te informacje zostają wykorzystane, aby nadać prędkość wirtualnej piłce i rozpoczyna się symulacja lotu piłki.

- W czwartej fazie, piłka styka się z podłożem i zostaje wyhamowana. Wtedy też zostają wyświetlone statystyki rzutu, takie jak: prędkość rzutu, kąt wyrzutu oraz odległość rzutu.

Na rysunkach od 4 do 6 pokazano widok aplikacji w trzech kolejnych momentach działania.

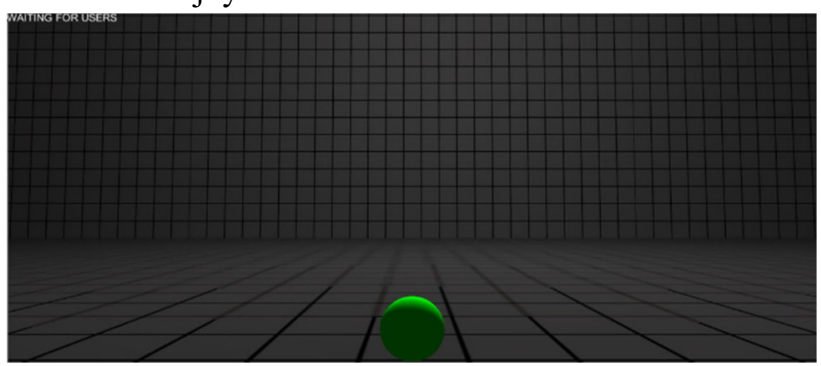

Rysunek 4: Widok aplikacji przed wykryciem użytkownika.

Na rysunku powyższym (Rys. 4) zademonstrowano widok aplikacji w fazie uruchomiania, kiedy użytkownik jeszcze nie jest wykrywany przez kontroler Kinecta.

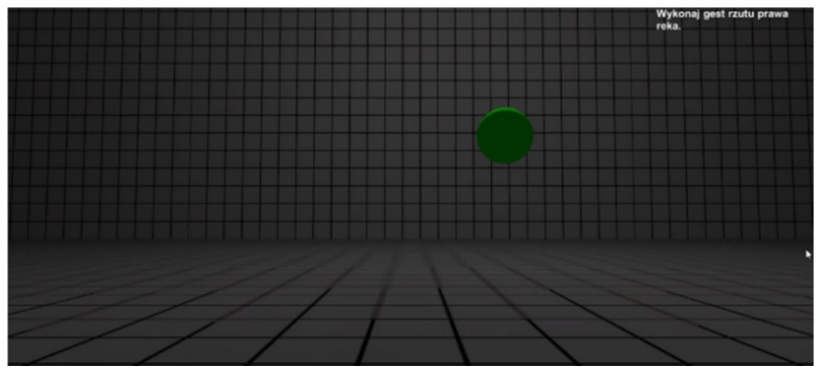

Rysunek 5: Widok aplikacji po wykryciu użytkownika.

Widok aplikacji, kiedy użytkownik zostanie wykryty (Rys 5). Piłka zaczyna poruszać się tak jak ręka w rzeczywistości. Zostaje wyświetlony komunikat, aby wykonać gest rzutu. Następuje iteracyjna weryfikacja, czy zostały spełnione warunki konieczny, aby ruch ręki zaliczyć jako rzut.

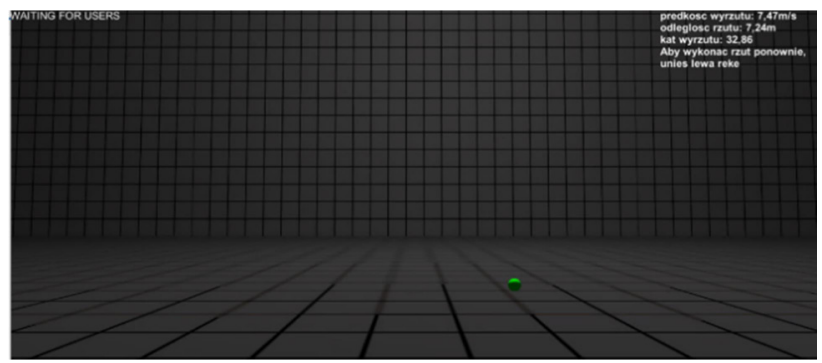

Rysunek 6: Widok aplikacji po wykonanym geście rzutu i skończonej symulacji lotu piłki.

Na rysunku powyższym (Rys. 6) przedstawiono widok aplikacji, kiedy został poprawnie wykryty gest rzutu. Zostaje wykonana symulacja lotu piłki oraz wyświetlona statystyki lotu, którymi są: prędkość wyrzutu, odległość i kąt rzutu. Po zakończonej symulacji jest 
informacja, że w celu wykonania ponownie rzutu należy podnieść lewą rękę.

Na rysunku 7 pokazano widok wirtualnego szkieletu podczas wykonywania gestu rzutu.

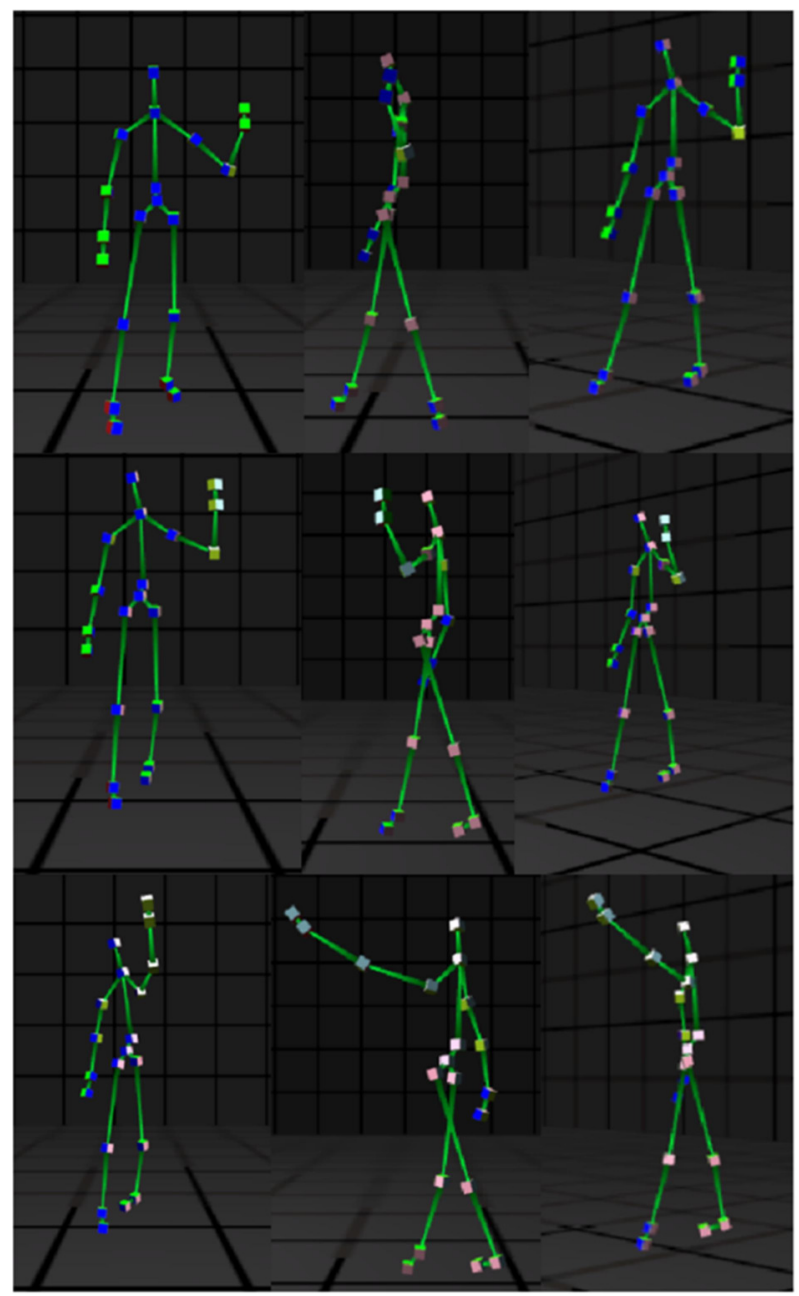

Rysunek 7: Widok wirtualnego szkieletu użytkownika podczas $3 \mathrm{faz}$ rzutu.

Podczas wykonywania rzutu zbadano koordynaty $\mathrm{x}$, y i z prawej dłoni, którą jest wykonywany rzut.

Koordynat $\mathrm{x}$ to jest przesunięcie prawo - lewo względem Kinect'a. Koordynat y to jest przesunięcie góra dół względem Kinect'a. Koordynat $z$ to jest przesunięcie przód - tył względem Kinect'a.

Dla pierwszej fazy rzutu, gdzie dłoń jest przy barku koordynaty wynosiły:

$\mathrm{x}=0,438, \mathrm{y}=0,571, \mathrm{z}=0,132$.

Dla drugiej fazy rzutu, gdzie ręka jest w ruchu koordynaty wynosiły:

$\mathrm{x}=0,355, \mathrm{y}=0,634, \mathrm{z}=-0,112$.

Dla trzeciej fazy rzutu, gdzie ręka już wykonała rzut, koordynaty wynosiły:

$\mathrm{x}=0,315, \mathrm{y}=0,793, \mathrm{z}=-0,552$

\section{Wyniki badań}

Tabele od 1 do 3 pokazują wyniki badania wychwytywanego kata rzutu przed Kinect'em. Poniżej zaprezentowano uzyskane wyniki $\mathrm{w}$ trzech tabelach $\mathrm{z}$ trzech stanowisk wspomnianych na rysunku 1 .

Błąd względny był wyliczany na podstawie wzoru:

$$
\Delta x=\left|x-x_{0}\right|
$$

Błąd bezwzględny był wyliczany na podstawie wzoru:

$$
\delta=\frac{\Delta x}{x} * 100 \%=\frac{\left|x-x_{0}\right|}{x} * 100 \%
$$

\begin{tabular}{|c|c|c|c|c|c|c|}
\hline \multirow[b]{2}{*}{ 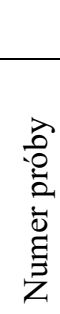 } & \multicolumn{3}{|c|}{ Sprawdzany kąt 30} & \multicolumn{3}{|c|}{ Sprawdzany kąt 45} \\
\hline & 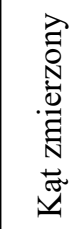 & 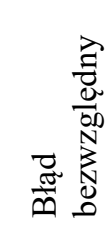 & 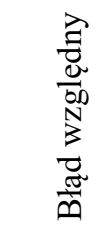 & 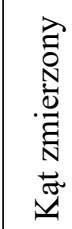 & 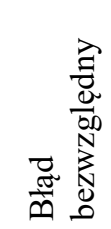 & 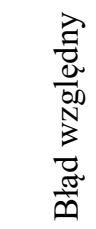 \\
\hline 1 & $38^{\circ}$ & $8^{\circ}$ & $26,7 \%$ & $45^{\circ}$ & $0^{\circ}$ & $0,0 \%$ \\
\hline 2 & $30^{\circ}$ & $0^{\circ}$ & $0,0 \%$ & $45^{\circ}$ & $0^{\circ}$ & $0,0 \%$ \\
\hline 3 & $32^{\circ}$ & $2^{\circ}$ & $6,7 \%$ & $42^{\circ}$ & $3^{\circ}$ & $6,7 \%$ \\
\hline 4 & $35^{\circ}$ & $5^{\circ}$ & $16,7 \%$ & $43^{\circ}$ & $2^{\circ}$ & $4,4 \%$ \\
\hline 5 & $32^{\circ}$ & $2^{\circ}$ & $6,7 \%$ & $39^{\circ}$ & $6^{\circ}$ & $13,3 \%$ \\
\hline 6 & $25^{\circ}$ & $5^{\circ}$ & $16,7 \%$ & $44^{\circ}$ & $1^{\circ}$ & $2,2 \%$ \\
\hline 7 & $30^{\circ}$ & $0^{\circ}$ & $0,0 \%$ & $47^{\circ}$ & $2^{\circ}$ & $4,4 \%$ \\
\hline 8 & $31^{\circ}$ & $1^{\circ}$ & $3,3 \%$ & $42^{\circ}$ & $3^{\circ}$ & $6,7 \%$ \\
\hline 9 & $33^{\circ}$ & $3^{\circ}$ & $10,0 \%$ & $47^{\circ}$ & $2^{\circ}$ & $4,4 \%$ \\
\hline 10 & $35^{\circ}$ & $5^{\circ}$ & $16,7 \%$ & $42^{\circ}$ & $3^{\circ}$ & $6,7 \%$ \\
\hline
\end{tabular}

Tabela 1: Wyniki ze stanowiska nr 1 .

\begin{tabular}{|c|c|c|c|c|c|c|}
\hline & \multicolumn{3}{|c|}{ Sprawdzany kąt 30} & \multicolumn{3}{|c|}{ Sprawdzany kąt 45} \\
\hline 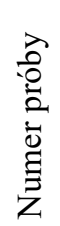 & 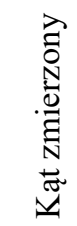 & 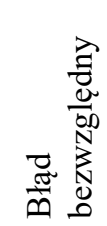 & 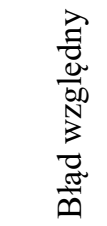 & 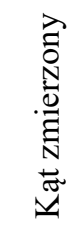 & 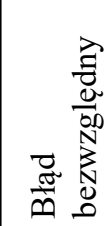 & 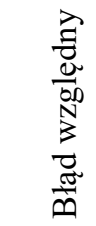 \\
\hline 1 & $33^{\circ}$ & $3^{\circ}$ & $10,0 \%$ & $39^{\circ}$ & $6^{\circ}$ & $13,3 \%$ \\
\hline 2 & $30^{\circ}$ & $0^{\circ}$ & $0,0 \%$ & $39^{\circ}$ & $6^{\circ}$ & $13,3 \%$ \\
\hline 3 & $37^{\circ}$ & $7^{\circ}$ & $23,3 \%$ & $42^{\circ}$ & $3^{\circ}$ & $6,7 \%$ \\
\hline 4 & $29^{\circ}$ & $1^{\circ}$ & $3,3 \%$ & $35^{\circ}$ & $10^{\circ}$ & $22,2 \%$ \\
\hline 5 & $32^{\circ}$ & $2^{\circ}$ & $6,7 \%$ & $39^{\circ}$ & $6^{\circ}$ & $13,3 \%$ \\
\hline 6 & $28^{\circ}$ & $2^{\circ}$ & $6,7 \%$ & $41^{\circ}$ & $4^{\circ}$ & $8,9 \%$ \\
\hline 7 & $37^{\circ}$ & $7^{\circ}$ & $23,3 \%$ & $44^{\circ}$ & $1^{\circ}$ & $2,2 \%$ \\
\hline 8 & $26^{\circ}$ & $4^{\circ}$ & $13,3 \%$ & $45^{\circ}$ & $0^{\circ}$ & $0,0 \%$ \\
\hline 9 & $25^{\circ}$ & $5^{\circ}$ & $16,7 \%$ & $42^{\circ}$ & $3^{\circ}$ & $6,7 \%$ \\
\hline 10 & $32^{\circ}$ & $2^{\circ}$ & $6,7 \%$ & $43^{\circ}$ & $2^{\circ}$ & $4,4 \%$ \\
\hline
\end{tabular}

Tabela 2: Wyniki ze stanowiska nr 2. 
Tabela 3: Wyniki ze stanowiska nr 3.

\begin{tabular}{|c|c|c|c|c|c|c|}
\hline \multirow[b]{2}{*}{ 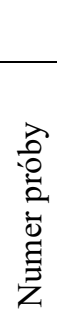 } & \multicolumn{3}{|c|}{ Sprawdzany kąt $30^{\circ}$} & \multicolumn{3}{|c|}{ Sprawdzany kąt $45^{\circ}$} \\
\hline & 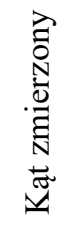 & 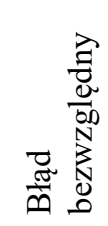 & 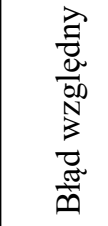 & 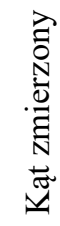 & 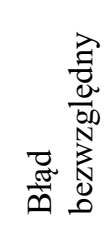 & 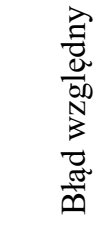 \\
\hline 1 & $35^{\circ}$ & $5^{\circ}$ & $16,7 \%$ & $42^{\circ}$ & $3^{\circ}$ & $6,7 \%$ \\
\hline 2 & $33^{\circ}$ & $3^{\circ}$ & $10,0 \%$ & $40^{\circ}$ & $5^{\circ}$ & $11,1 \%$ \\
\hline 3 & $30^{\circ}$ & $0^{\circ}$ & $0,0 \%$ & $48^{\circ}$ & $3^{\circ}$ & $6,7 \%$ \\
\hline 4 & $32^{\circ}$ & $2^{\circ}$ & $6,7 \%$ & $42^{\circ}$ & $3^{\circ}$ & $6,7 \%$ \\
\hline 5 & $37^{\circ}$ & $7^{\circ}$ & $23,3 \%$ & $35^{\circ}$ & $10^{\circ}$ & $22,2 \%$ \\
\hline 6 & $32^{\circ}$ & $2^{\circ}$ & $6,7 \%$ & $44^{\circ}$ & $1^{\circ}$ & $2,2 \%$ \\
\hline 7 & $28^{\circ}$ & $2^{\circ}$ & $6,7 \%$ & $40^{\circ}$ & $5^{\circ}$ & $11,1 \%$ \\
\hline 8 & $26^{\circ}$ & $4^{\circ}$ & $13,3 \%$ & $43^{\circ}$ & $2^{\circ}$ & $4,4 \%$ \\
\hline 9 & $29^{\circ}$ & $1^{\circ}$ & $3,3 \%$ & $42^{\circ}$ & $3^{\circ}$ & $6,7 \%$ \\
\hline 10 & $29^{\circ}$ & $1^{\circ}$ & $3,3 \%$ & $45^{\circ}$ & $0^{\circ}$ & $0,0 \%$ \\
\hline
\end{tabular}

Dla stanowiska nr 1 dla kąta $30^{\circ}$ średnia z prób wynosi $32.10^{\circ}$ mediana $32^{\circ}$ a odchylenie standardowe $3,54^{\circ}$. Dla kąta $45^{\circ}$ średnia wynosi $43,60^{\circ}$ mediana $43,50^{\circ}$ a odchylenie standardowe $2,50^{\circ}$.

Dla stanowiska nr 2 dla kąta $30^{\circ}$ średnia z prób wynosi $30,90^{\circ}$ mediana $31^{\circ}$ a odchylenie standardowe $4,12^{\circ}$. Dla kąta $45^{\circ}$ średnia wynosi $40,90^{\circ}$ mediana $41,50^{\circ}$ a odchylenie standardowe $2,96^{\circ}$.

Dla stanowiska nr 3 dla kąta $30^{\circ}$ średnia z prób wynosi $31.10^{\circ}$ mediana $31^{\circ}$ a odchylenie standardowe $3,35^{\circ}$. Dla kąta $45^{\circ}$ średnia wynosi $42,10^{\circ}$ mediana $42^{\circ}$ a odchylenie standardowe $3,45^{\circ}$.

Po przeprowadzonych pomiarach dla kąta $30^{\circ}$ widać, że między stanowiskami nie ma dużych różnic, jeżeli chodzi o błąd względny i błąd bezwzględny. Dla trzech stanowisk błąd względny wyniósł $3^{\circ}$ a błąd bezwzględny wyniósł $10 \%$.

Po przeprowadzonych pomiarach dla kąta $45^{\circ}$ wi-

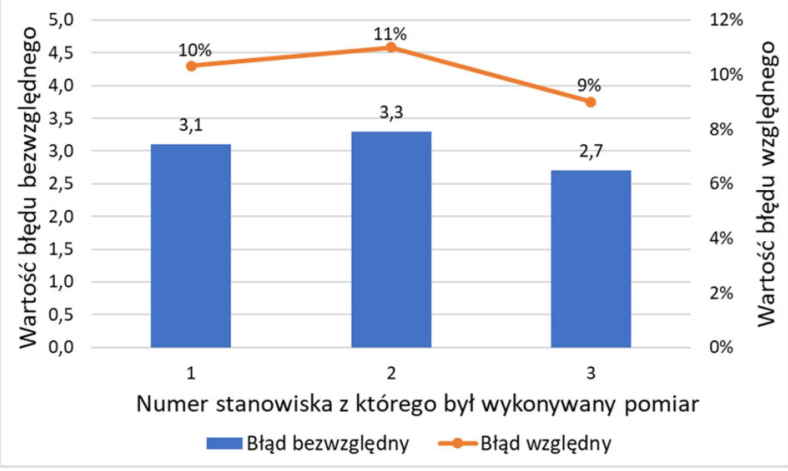

Rysunek 8: Wykres porównujący błąd względny i bezwzględny dla badanego kąta $30^{\circ}$ między stanowiskami. dać, że między stanowiskami nie ma dużych różnic, jeżeli chodzi o błąd względny i błąd bezwzględny. Dla trzech stanowisk błąd względny wyniósł $3^{\circ}$ a błąd bezwzględny wyniósł 7\%.

W tym badaniu dla każdego stanowiska było wykonanych po 10 pomiarów. Dla badanego kąta $30^{\circ}$ najbliższa średnia wniosła $30.90^{\circ}$, kiedy rzut był wykonywany na stanowisku 2. W przypadku stanowiska 1 średnia wynosiła $32.10^{\circ}$ a stanowiska $3-31.10^{\circ}$. Pokazuje to, że różnica pomiędzy wynosi $1.20^{\circ}$ między najbliższym a najdalszym wynikiem. Dodatkowo różnica pomiędzy kątami uzyskanymi a pożądanymi wynosi od $0.9^{\circ}$ to $2.1^{\circ}$. W przypadku badanego kąta $45^{\circ}$ najbliższą średnią było $43.60^{\circ}$, kiedy badanie było wykonane na stanowisku 1 . Gest przeprowadzony na stanowisku 2 dał wynik $40.90^{\circ}$ a stanowisku $3-42.10^{\circ}$. Daje to $3.70^{\circ}$ różnicy pomiędzy najmniejszą a największą średnią. Patrząc na różnice od kąta $45^{\circ}$ daje od $1.40^{\circ}$ do $4.10^{\circ}$.

Patrząc natomiast na oddalenie wszystkich wartości od średniej w przypadku badanego kąta $30^{\circ}$ najmniejszą wartością jest $3.35^{\circ}$ przy badaniu ze stanowiska $3,3.54^{\circ}$ przy badaniu na stanowisku 2 , a największą $4.12^{\circ}$ przy badaniu ze stanowiska 3 . Przy kącie $45^{\circ}$ najmniejszą wartością jest $2.50^{\circ}$ dla badania na stanowisku $1,2.96^{\circ}$ przy badaniu ze stanowiska 2 oraz największą wartością jest $3.45^{\circ} \mathrm{W}$ przypadku stanowiska 3 .

W tabeli 4 przedstawiono wyniki badań rzutów przed Kinect'em i w rzeczywistości. Rzut rzeczywisty

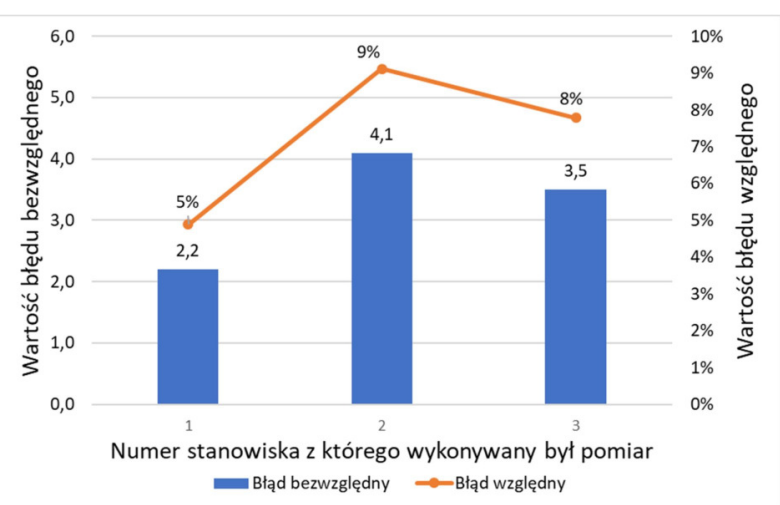

Rysunek 9: Wykres porównujący błąd względny i bezwzględny dla badanego kąta $45^{\circ}$ między stanowiskami.

został wykonany na świeżym powietrzu w warunkach możliwie bezwietrznych, aby jak najdokładniej wykonać pomiary.

Przy obliczaniu wartości błędu względnego i bezwzględnego wartością uznaną za rzeczywistą była średnia $\mathrm{z}$ rzutów rzeczywistych $\mathrm{w}$ danym badaniu. 
Tabela 4: Wyniki badania 2.

\begin{tabular}{|c|c|c|c|c|c|c|c|c|c|c|c|c|c|c|c|c|c|c|c|}
\hline \multicolumn{5}{|c|}{ Badanie nr 1} & \multicolumn{5}{|c|}{ Badanie $\mathrm{nr} 2$} & \multicolumn{5}{|c|}{ Badanie $\mathrm{nr} 3$} & \multicolumn{5}{|c|}{ Badanie nr 4} \\
\hline 1.p. & 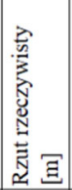 & $\mid \begin{array}{l}5 \\
3 \\
3 \\
0 \\
\text { 音五 }\end{array}$ & 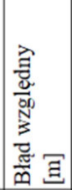 & 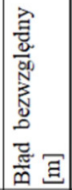 & 1.p. & 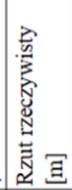 & 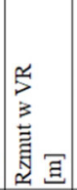 & 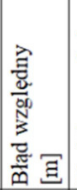 & 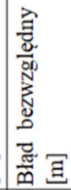 & 1.p. & 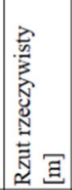 & 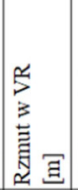 & 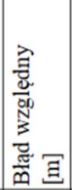 & 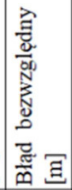 & l.p. & 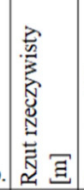 & 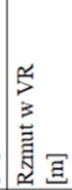 & 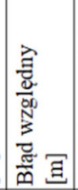 & 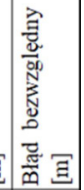 \\
\hline 1 & 6,50 & 4,40 & 1,60 & $27 \%$ & 1 & 8,20 & 8,20 & 0,10 & $1 \%$ & 1 & 11,00 & 10,50 & 0,48 & $4 \%$ & 1 & 112,90 & 11,00 & 2,94 & \begin{tabular}{|l|l|}
4 & $21 \%$ \\
\end{tabular} \\
\hline 2 & 5,00 & 10,00 & 4,00 & $67 \%$ & 2 & 8,30 & 5,00 & 3,10 & $38 \%$ & 2 & 10,60 & 6,00 & 4,98 & $45 \%$ & 2 & 212,40 & 12,40 & 1,54 & \begin{tabular}{|l|l|}
4 & $11 \%$ \\
\end{tabular} \\
\hline 3 & 6,30 & 3,00 & 3,00 & $50 \%$ & 3 & 7,70 & 8,20 & 0,10 & $1 \%$ & 3 & 11,20 & 15,00 & 4,02 & $37 \%$ & 3 & \begin{tabular}{|l|l|}
3 & 17,70 \\
\end{tabular} & 13,00 & 0,94 & $7 \%$ \\
\hline 4 & 6,40 & 6,20 & 0,20 & $3 \%$ & 4 & 8,00 & 12,00 & 3,90 & $48 \%$ & 4 & 11,70 & 11,00 & 0,02 & $0 \%$ & 4 & \begin{tabular}{|l|l|}
4 & 12,60 \\
\end{tabular} & 7,00 & 6,94 & \begin{tabular}{|l|l|}
4 & $50 \%$ \\
\end{tabular} \\
\hline 5 & 5,80 & 5,80 & 0,20 & $3 \%$ & 5 & 8,30 & 7,50 & 0,60 & $7 \%$ & 5 & 10,40 & 9,00 & 1,98 & $18 \%$ & 5 & \begin{tabular}{|l|l|}
5 & 14,10 \\
\end{tabular} & 13,30 & 0,64 & $5 \%$ \\
\hline rednia & 6,00 & 5,88 & 1,80 & $30 \%$ & średnia & 8,10 & 8,18 & 1,56 & \begin{tabular}{l|l}
5 & $19 \%$ \\
\end{tabular} & Śsednia & 10,98 & 10,30 & 2,30 & $21 \%$ & f́srednia & 13,94 & 11,34 & 2,60 & \begin{tabular}{l|l|}
0 & $19 \%$ \\
\end{tabular} \\
\hline $\begin{array}{l}\text { odchylenie } \\
\text { standardowe }\end{array}$ & 1,54 & 27,6 & & & \begin{tabular}{|l|} 
odchylenie \\
standardowe
\end{tabular} & 0,26 & 25,2 & & & \begin{tabular}{|l|} 
odchylenie \\
standardowe
\end{tabular} & 1,05 & 42,8 & & & \begin{tabular}{|l|} 
odchylenie \\
standardowe
\end{tabular} & 19,4 & 26,7 & & \\
\hline \multicolumn{5}{|c|}{ Badanie nr 5} & \multicolumn{5}{|c|}{ Badanie nr 6} & \multicolumn{5}{|c|}{ Badanie nr 7} & \multicolumn{5}{|c|}{ Badanie nr 8} \\
\hline 1.p. & 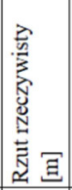 & 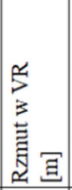 & 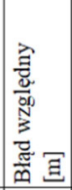 & 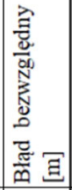 & 1.p. & 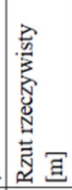 & 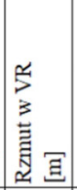 & 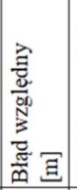 & 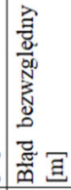 & 1.p. & 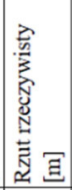 & 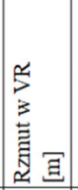 & 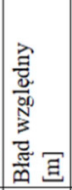 & 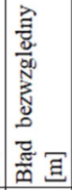 & 1.p. & 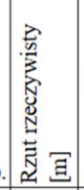 & 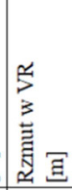 & 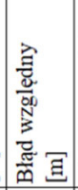 & 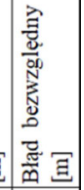 \\
\hline 1 & 6,10 & 7,20 & 1,06 & $21 \%$ & 1 & 8,00 & 7,00 & 1,26 & $\begin{array}{ll}5 & 15 \% \\
\end{array}$ & 1 & 11,60 & 11,20 & 0,68 & $6 \%$ & 1 & 115,00 & 14,50 & 0,52 & \begin{tabular}{|l|l|}
2 & $3 \%$ \\
\end{tabular} \\
\hline 2 & 6,00 & 6,80 & 0,66 & $13 \%$ & 2 & 7,90 & 10,00 & 1,74 & $21 \%$ & 2 & 11,70 & 10,80 & 1,08 & $9 \%$ & 2 & \begin{tabular}{|l|l|}
2 & 14,40 \\
\end{tabular} & 13,80 & 1,22 & $8 \%$ \\
\hline 3 & 5,80 & 8,00 & 1,86 & $36 \%$ & 3 & 8,10 & 8,00 & 0,26 & \begin{tabular}{|l|l|}
5 & $3 \%$ \\
\end{tabular} & 3 & 12,60 & 8,90 & 2,98 & $25 \%$ & 3 & \begin{tabular}{|l|l|}
3 & 15,50 \\
\end{tabular} & 17,00 & 1,98 & \begin{tabular}{|l|l|}
8 & $13 \%$ \\
\end{tabular} \\
\hline 4 & 6,40 & 6,00 & 0,14 & $3 \%$ & 4 & 8,90 & 8,50 & 0,24 & $3 \%$ & 4 & 11,50 & 12,00 & 0,12 & $1 \%$ & 4 & \begin{tabular}{|l|l|}
4 & 15,00 \\
\end{tabular} & 20,00 & 4,98 & \begin{tabular}{|l|l|}
8 & $33 \%$ \\
\end{tabular} \\
\hline 5 & 6,40 & 10,00 & 3,86 & $75 \%$ & 5 & 8,40 & 6,00 & 2,26 & \begin{tabular}{|l|l|}
5 & $27 \%$ \\
\end{tabular} & 5 & 12,00 & 13,00 & 1,12 & $9 \%$ & 5 & \begin{tabular}{|l|l|}
5 & 15,20 \\
\end{tabular} & 15,00 & 0,02 & \begin{tabular}{|l|l|}
2 & $0 \%$ \\
\end{tabular} \\
\hline rednia & 6,14 & 7,60 & 1,52 & $29 \%$ & średnia & 8,26 & 7,90 & 1,15 & $14 \%$ & średnia & $\mid 11,88$ & 11,18 & 1,20 & $10 \%$ & średnia & 15,02 & 16,06 & 1,74 & \begin{tabular}{|l|l|}
4 & $12 \%$ \\
\end{tabular} \\
\hline $\begin{array}{l}\text { odchylenie } \\
\text { standardowe }\end{array}$ & 0,27 & 9,28 & & & \begin{tabular}{|l|}
$\begin{array}{l}\text { odchylenie } \\
\text { standardowe }\end{array}$ \\
\end{tabular} & 0,65 & 9,2 & & & \begin{tabular}{|l|} 
odchylenie \\
standardowe
\end{tabular} & 0,79 & 9,33 & & & \begin{tabular}{|l|}
$\begin{array}{l}\text { odchylenie } \\
\text { standardowe }\end{array}$ \\
\end{tabular} & 0,65 & 25,1 & & \\
\hline \multicolumn{5}{|c|}{ Badanie $n$ r 9} & \multicolumn{5}{|c|}{ Badanie nr 10} & \multicolumn{5}{|c|}{ Badanie nr 11} & \multicolumn{5}{|c|}{ Badanie $\mathrm{nr} 12$} \\
\hline 1.p. & 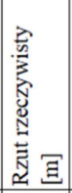 & $\begin{array}{l}\text { S } \\
3 \\
3 \\
\text { 音 } \\
\text { 国 }\end{array}$ & 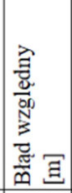 & 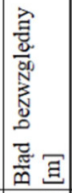 & 1.p. & 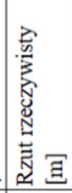 & 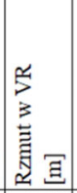 & 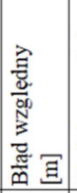 & 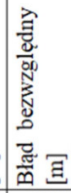 & 1.p. & 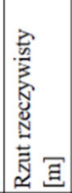 & 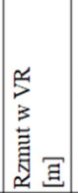 & 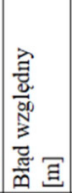 & 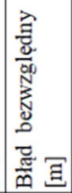 & 1.p. & 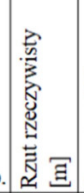 & 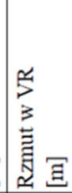 & 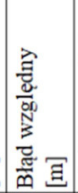 & 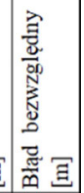 \\
\hline 1 & 8,00 & 8,50 & 0,02 & $0 \%$ & 1 & 10,50 & 9,40 & 1,18 & $\begin{array}{ll}11 \% \\
\end{array}$ & 1 & 12,40 & 8,00 & 3,90 & $33 \%$ & 1 & 144,00 & 9,00 & 4,80 & \begin{tabular}{|l|l|}
0 & $35 \%$ \\
\end{tabular} \\
\hline 2 & 9,00 & 5,10 & 3,42 & $40 \%$ & 2 & 11,30 & 7,30 & 3,28 & \begin{tabular}{l|l}
$31 \%$ \\
\end{tabular} & 2 & 11,80 & 12,30 & 0,40 & $3 \%$ & 2 & \begin{tabular}{|l|l|}
2 & 13,20 \\
\end{tabular} & 11,00 & 2,80 & \begin{tabular}{|l|l|}
0 & $20 \%$ \\
\end{tabular} \\
\hline 3 & 8,10 & 8,00 & 0,52 & $6 \%$ & 3 & 10,60 & 10,30 & 0,28 & $\begin{array}{l}3 \% \\
3\end{array}$ & 3 & 11,70 & 11,70 & 0,20 & $2 \%$ & 3 & \begin{tabular}{|l|l|}
34,30 \\
\end{tabular} & 14,00 & 0,20 & $1 \%$ \\
\hline 4 & 9,20 & 9,90 & 1,38 & $16 \%$ & 4 & 10,10 & 11,00 & 0,42 & $4 \%$ & & 11,60 & 12,00 & 0,10 & $1 \%$ & & \begin{tabular}{|l|l|}
4 & 13,10 \\
\end{tabular} & 13,10 & 0,70 & $5 \%$ \\
\hline 5 & 8,30 & 8,10 & 0,42 & $5 \%$ & 5 & 10,40 & 14,60 & 4,02 & $38 \%$ & 5 & 12,00 & 11,90 & 0,00 & $0 \%$ & 5 & \begin{tabular}{|l|l|}
5 & 14,40 \\
\end{tabular} & 17,00 & 3,20 & \begin{tabular}{|l|l|}
0 & $23 \%$ \\
\end{tabular} \\
\hline srednia & 8,52 & 7,92 & 1,15 & $14 \%$ & średnia & 10,58 & 10,52 & 1,84 & $17 \%$ & Śsrednia & 11,90 & 11,18 & 0,92 & $8 \%$ & f́średnia & 13,80 & 12,82 & 2,34 & \begin{tabular}{|l|l|}
4 & $17 \%$ \\
\end{tabular} \\
\hline $\begin{array}{l}\text { odchylenie } \\
\text { standardowe }\end{array}$ & 1,19 & 12,25 & & & \begin{tabular}{|l|}
$\begin{array}{l}\text { odchylenie } \\
\text { standardowe }\end{array}$ \\
\end{tabular} & 0,79 & 28,55 & & & \begin{tabular}{|l|}
$\begin{array}{l}\text { odchylenie } \\
\text { standardowe }\end{array}$ \\
\end{tabular} & 0,40 & 12,83 & & & \begin{tabular}{|l|}
$\begin{array}{l}\text { odchylenie } \\
\text { standardowe }\end{array}$ \\
\end{tabular} & 1,50 & 36,85 & & \\
\hline \multicolumn{5}{|c|}{ Badanie nr 13} & \multicolumn{5}{|c|}{ Badanie nr 14} & \multicolumn{5}{|c|}{ Badanie nr 15} & \multicolumn{5}{|c|}{ Badanie nr 16} \\
\hline 1.p. & 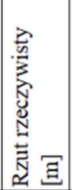 & $\mid \begin{array}{l}5 \\
3 \\
3 \\
\text { 音金 }\end{array}$ & 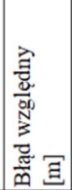 & 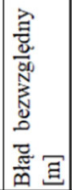 & 1.p. & 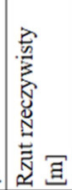 & $\mid \begin{array}{l}\stackrel{\mu}{5} \\
3 \\
\text { 音 } \\
\text { 互 }\end{array}$ & 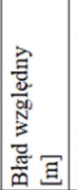 & 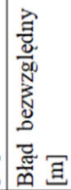 & 1.p. & 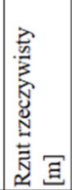 & 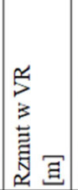 & 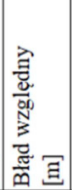 & 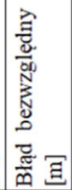 & 1.p. & 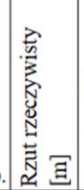 & $\begin{array}{l}5 \\
3 \\
3 \\
\text { 范金 }\end{array}$ & 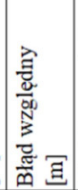 & 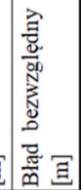 \\
\hline 1 & 7,50 & 6,80 & 0,88 & $11 \%$ & 1 & 10,20 & 7,00 & 3,34 & $32 \%$ & 1 & 11,00 & 6,00 & 5,46 & $48 \%$ & & 113,50 & 17,00 & 3,50 & 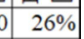 \\
\hline 2 & 7,70 & 7,50 & 0,18 & $2 \%$ & 2 & 10,90 & 9,40 & 0,94 & $9 \%$ & 2 & 11,50 & 9,00 & 2,46 & $21 \%$ & 2 & \begin{tabular}{|l|l|}
2 & 14,00 \\
\end{tabular} & 13,00 & 0,50 & $4 \%$ \\
\hline 3 & 8,00 & 10,00 & 2,32 & $30 \%$ & 3 & 11,00 & 14,00 & 3,66 & \begin{tabular}{l|l|}
$555 \%$ \\
\end{tabular} & 3 & 11,60 & 12,00 & 0,54 & $5 \%$ & 3 & \begin{tabular}{|l|l|}
34,30 \\
\end{tabular} & 14,20 & 0,70 & $5 \%$ \\
\hline 4 & 8,00 & 8,00 & 0,32 & $4 \%$ & 4 & 9,90 & 10,30 & 0,04 & $0 \%$ & 4 & 11,00 & 11,50 & 0,04 & $0 \%$ & 4 & \begin{tabular}{|l|l|}
4 & 13,20 \\
\end{tabular} & 10,00 & 3,50 & \begin{tabular}{|l|l|}
0 & $26 \%$ \\
\end{tabular} \\
\hline 5 & 7,20 & 4,00 & 3,68 & $48 \%$ & 5 & 9,70 & 10,00 & 0,34 & $3 \%$ & 5 & 12,20 & 11,00 & 0,46 & $4 \%$ & 5 & \begin{tabular}{|l|l|}
5 & 12,50 \\
\end{tabular} & 12,70 & 0,80 & $6 \%$ \\
\hline srednia & 7,68 & 7,26 & 1,48 & $19 \%$ & średnia & 10,34 & 10,14 & 1,66 & $\begin{array}{ll} \\
\end{array}$ & Średnia & \begin{tabular}{|l|}
11,46 \\
\end{tabular} & \begin{tabular}{|l|}
9,90 \\
\end{tabular} & 1,79 & $16 \%$ & fir & 13,50 & 13,38 & 1,80 & \begin{tabular}{|l|l|}
0 & $13 \%$ \\
\end{tabular} \\
\hline $\begin{array}{l}\text { odchylenie } \\
\text { standardowe }\end{array}$ & 0,47 & 18,95 & & & \begin{tabular}{|l|}
$\begin{array}{l}\text { odchylenie } \\
\text { standardowe }\end{array}$ \\
\end{tabular} & 1,37 & 25,35 & & & \begin{tabular}{|l|}
$\begin{array}{l}\text { odchylenie } \\
\text { standardowe }\end{array}$ \\
\end{tabular} & 0,99 & 24,20 & & & \begin{tabular}{|l|}
$\begin{array}{l}\text { odchylenie } \\
\text { standardowe }\end{array}$ \\
\end{tabular} & 1,98 & \begin{tabular}{|l|l|} 
& 25,81 \\
\end{tabular} & & \\
\hline \multicolumn{5}{|c|}{ Badanie nr 17} & & Badan & ie nr 18 & & & & Badan & ie nr 19 & & & & Badani & hie $\mathrm{nr} 20$ & & \\
\hline 1.p. & 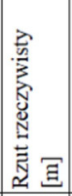 & $\begin{array}{l}\text { S } \\
3 \\
3 \\
\text { 范 } \\
\text { 国 }\end{array}$ & 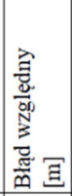 & 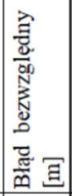 & 1.p. & 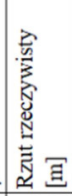 & $\mid \begin{array}{l}\text { 号 } \\
3 \\
\text { 音 } \\
\text { 琶 }\end{array}$ & 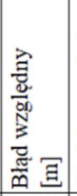 & 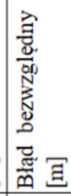 & 1.p. & 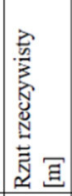 & 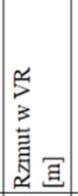 & 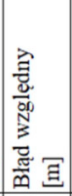 & 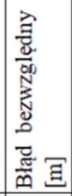 & 1.p. & 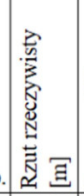 & $\begin{array}{l}\text { 点 } \\
3 \\
\text { 范 } \\
\text { 金 }\end{array}$ & 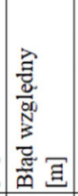 & 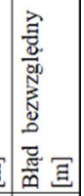 \\
\hline 1 & 4,80 & 3,00 & 1,84 & $38 \%$ & 1 & 9,60 & 8,00 & 2,70 & $25 \%$ & 1 & 15,00 & 12,00 & 3,30 & $22 \%$ & 1 & 118,00 & 17,00 & 1,56 & $8 \%$ \\
\hline 2 & 4,20 & 4,90 & 0,06 & $1 \%$ & 2 & 10,20 & 9,40 & 1,30 & $12 \%$ & 2 & 15,30 & 16,50 & 1,20 & $8 \%$ & 2 & 219,30 & 18,50 & 0,06 & $0 \%$ \\
\hline 3 & 5,30 & 5,00 & 0,16 & $3 \%$ & 3 & 12,00 & 11,90 & 1,20 & $11 \%$ & 3 & \begin{tabular}{|l|}
6,10 \\
\end{tabular} & 18,00 & 2,70 & $18 \%$ & 3 & \begin{tabular}{|l|l|}
318,50 \\
\end{tabular} & 19,00 & 0,44 & $2 \%$ \\
\hline 4 & 5,00 & 8,00 & 3,16 & $65 \%$ & 4 & 11,10 & 10,30 & 0,40 & $4 \%$ & 4 & \begin{tabular}{|l|}
14,90 \\
\end{tabular} & 15,00 & 0,30 & $2 \%$ & 4 & \begin{tabular}{|l|l|}
4 & 19,10 \\
\end{tabular} & 25,00 & 6,44 & \begin{tabular}{|l|l|}
4 & $35 \%$ \\
\end{tabular} \\
\hline & 4,90 & 4,40 & \begin{tabular}{|l|}
0,44 \\
\end{tabular} & $9 \%$ & 5 & $\begin{array}{l}10,60 \\
\end{array}$ & 11,20 & 0,50 & \begin{tabular}{|l|l}
$5 \%$ \\
\end{tabular} & 5 & \begin{tabular}{|l|}
15,20 \\
\end{tabular} & 16,20 & 0,90 & $6 \%$ & 5 & \begin{tabular}{|l|l|}
5 & 17,90 \\
\end{tabular} & 17,90 & 0,66 & $4 \%$ \\
\hline šrednia & 4,84 & 5,06 & 1,13 & $23 \%$ & średnia & \begin{tabular}{|l|l|}
10,70 \\
\end{tabular} & \begin{tabular}{|l|}
10,16 \\
\end{tabular} & 1,22 & $11 \%$ & średnia & \begin{tabular}{|l|}
15,30 \\
\end{tabular} & 15,54 & 1,68 & $11 \%$ & średnia & 18,56 & \begin{tabular}{|l|l|}
19,48 \\
\end{tabular} & 1,83 & 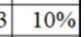 \\
\hline $\begin{array}{l}\text { odchylenie } \\
\text { standardowe }\end{array}$ & 0,65 & 13,35 & & & \begin{tabular}{|l|}
$\begin{array}{l}\text { odchylenie } \\
\text { standardowe }\end{array}$ \\
\end{tabular} & 3,32 & 9,37 & & & \begin{tabular}{|l|}
$\begin{array}{l}\text { odchylenie } \\
\text { standardowe }\end{array}$ \\
\end{tabular} & 0,90 & 20,23 & & & \begin{tabular}{|l|} 
odchylenie \\
standardowe
\end{tabular} & 1,59 & \begin{tabular}{|l|}
40,31 \\
\end{tabular} & & \\
\hline
\end{tabular}


Rysunki od 10 do 13 pokazują graficzną interpretacje wyników przeprowadzonego badania, w którym mierzono różnice pomiędzy pomiarem rzutu w VR a w rzeczywistości

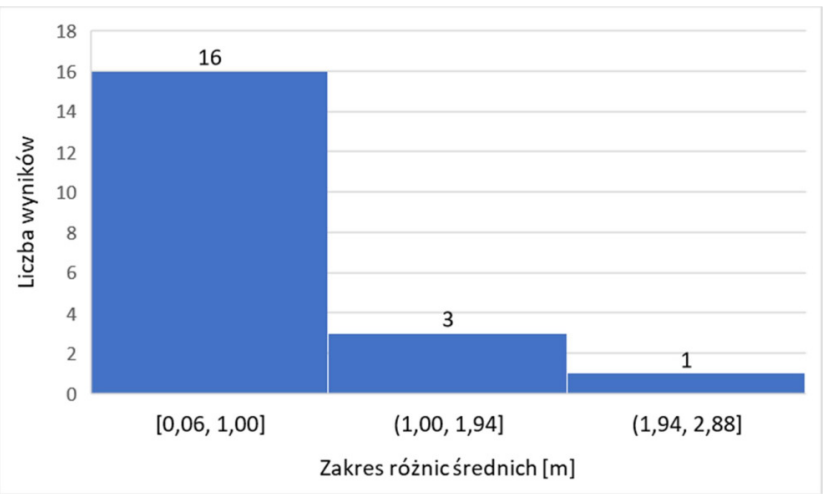

Rysunek 10: Histogram różnic pomiędzy średnimi z rzutu rzeczywistego i rzutu w wirtualnej rzeczywistości.

Badanie pokazujące różnice pomiędzy rzutem rzeczywistym a w wirtualnej rzeczywistości pokazują, że różnica średnich pomiędzy dwoma rodzajami rzutów nie jest większa niż $1,50 \mathrm{~m}$. Największą wartością jest $2,60 \mathrm{~m}$. W $16 \mathrm{z} 20$ badań ta różnica wynosiła poniżej $1 \mathrm{~m}$.

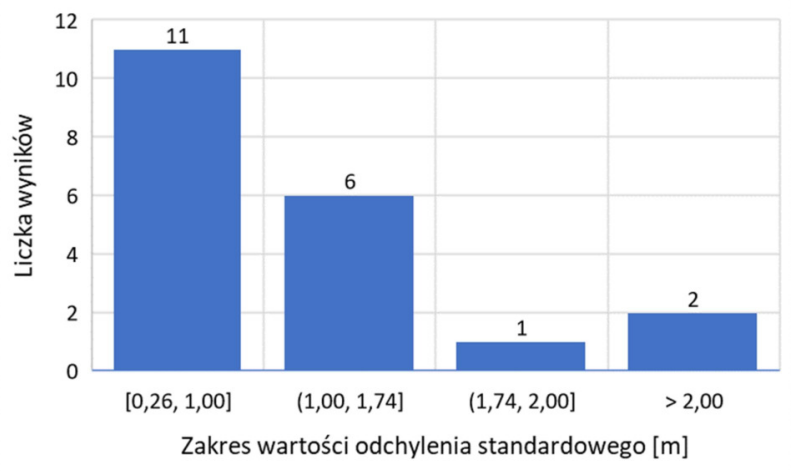

Rysunek 11: Histogram wyników odchyleń standardowych dla rzutu rzeczywistego.

Inaczej wygląda analiza odchyleń standardowych dwóch typów rzutów. W przypadku rzutu rzeczywistego, 11 z 20 rzutów miało odchylenie standardowe na poziomie do $1 \mathrm{~m}$. Kolejne $6 \mathrm{z} 20$ do $1,74 \mathrm{~m}$ a tylko 3 rzuty powyżej $1,74 \mathrm{~m}$. Pokazuje to dosyć niewielkie rozproszenie wyników rzutów.

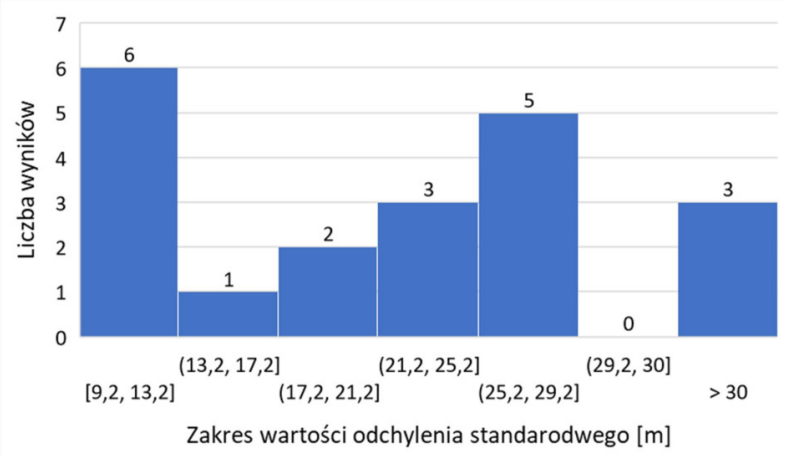

Rysunek 12: Histogram wyników odchyleń standardowych dla rzutu wirtualnego.
W przypadku rzutu w wirtualnej rzeczywistości najmniejszą wartością odchylenia standardowego było $9,20 \mathrm{~m}$. Wyniki 6 z 20 badań pokazało odchylenie standardowe na poziomie od 9,20 $\mathrm{m}$ do $13,20 \mathrm{~m}$. Kolejne 11 z 20 badań dało wyniki na poziomie od 13,20 m do 29,20 m a 3 z 30 badań dało wyniki powyżej $30 \mathrm{~m}$.

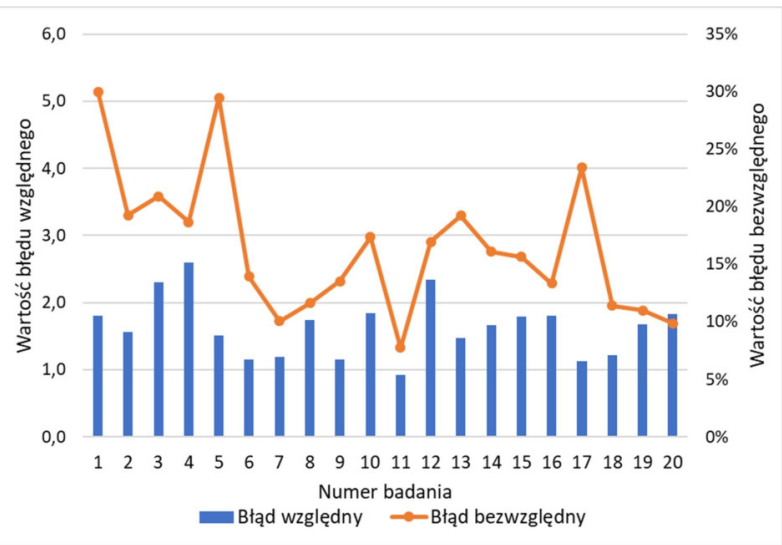

Rysunek 13: Wartości błędu względnego i błędu bezwzględnego w badaniu $\mathrm{nr} 2$.

Analiza błędów bezwzględnych i błędów względnych pokazuje, że dokładność pomiarów nie jest idealna. Dla 20 przebadanych osób, z których każda wykonała po 5 pomiarów rzeczywistych i wirtualnych wychodzi, że błąd bezwzględny średnio wynosi $16,47 \%$, a błąd względny wynosi średnio 1,64 m.

\section{Wnioski}

$\mathrm{Na}$ samym początku artykułu została przedstawiona technologia wirtualnej rzeczywistości. Zostały opracowane badania, które pozwolą sprawdzić precyzje działania Kinect'a. Następnie została opracowana i napisana aplikacja, za pomocą której można było przeprowadzić badania.

Wyniki przeprowadzonych badań pokazują, że technologia Kinect (pierwszej generacji) działa stosunkowo precyzyjnie. Jednak analiza wychwytywania kątów wykazała, że próby wykonywane przez człowieka nie były idealne. Świadczą o tym wyliczenia, które pokazują, że błąd bezwzględny wyniósł $10 \%$ dla kata 30 stopni oraz 7\% dla 45 stopni. Błąd względny wyniósł 3 stopnie dla obu badanych kątów. Należy zwrócić uwagę, na to, że pomiary były wykonywane ręcznie, a nie za pomocą np. mechanicznego ramienia. Takie ramie dałoby odpowiedni kąt i zostałby wtedy wykluczony błąd spowodowany nierównym ruchem przez człowieka. Dodać do tego należy, że wykorzystywana była najstarsza wersja Kinect'a, wyprodukowana w 2010 r. Jest ona o wiele mniej precyzyjna od nowszej wersji „Kinect v2 for Windows". Na podstawie filmów testowych załączonych w Internecie [7-10] można byłoby wywnioskować, że nowsza wersja dałaby dokładniejsze wyniki.

Następnym badaniem było porównanie odległości uzyskanych w rucie wirtualnym i rzeczywistym. Błąd bezwzględny wyniósł ponad 16\% a względny $1,64 \mathrm{~m}$. Różnice średnich pomiędzy oboma typami rzutów W zdecydowanej większości są niskie, wynoszą do $1 \mathrm{~m}$. Badając jednak odchylenie standardowe widać o wiele 
większe różnice. W przypadku rzutu rzeczywistego wartości 17 z 20 badań dochodzą do 1,74 m. Natomiast patrząc na wyniki z rzutu wirtualnego wartości zaczynają się od 9.2 m. Wyniki 17 z 20 wykazują odchylenie standardowe do $29 \mathrm{~m}$. Jest to duża różnica. Taki wynik może powodować kilka problemów. Jednym z nich jest stosunkowo niewielka liczba rejestrowanych klatek obrazu na sekundę. Jest ich 30 , co oznacza, że pozycja ciała jest rejestrowana co ok. $33 \mathrm{~ms}$. Ruch ręki wykonującej rzut trwa średnio 0.1-0.15 s, co oznacza, że łapanych jest od 3 do 5 pomiarów pozycji ciała. Jest to niską wartością i utrudnia precyzyjne wyliczenie siły rzutu. Dodatkowo przy sprawdzaniu działania wykonywanego programu, czasy pojedynczych pomiarów wynosiły pomiędzy $20 \mathrm{~ms}$ a $40 \mathrm{~ms}$, co przy przyjętej metodzie komplikowało wyliczanie prędkości piłki. Zastosowany algorytm, wyliczał prędkość dłoni pomiędzy każdym z wychwytywanych punktów, po czym największą prędkość wybierał jako moment oddania rzutu. Zdarzały się jednak bardzo często sytuacje, że koniec ruchu ręki, gdzie jej prędkość była największa następował w połowie pomiaru pozycji ciała, przez co algorytm wychwytywał mniejszą prędkość niż przy poprzednim pomiarze. Zostało to skorygowane, poprzez mnożenie ostatniej prędkości razy dwa, ponieważ taka wartość zazwyczaj była bliska prawdziwej.

W następnych wersjach aplikacji można zmienić model wykorzystywanego Kinect'a. Mogłoby zmniejszyć wagę niepoprawnych pomiarów oraz ustabilizować czasy pomiędzy pojedynczymi pomiarami. Dodatkowo można by napisać dokładniejszy algorytm wyliczający dokładną prędkość dłoni, który by rozwiązywał problem, który pojawia się, gdy ruch ręki kończy się przed ostatnim pomiarem. Wtedy rzut wirtualną piłką będzie maksymalnie zbliżony do tego wykonywanego w rzeczywistości.

\section{Literatura}

[1] Ł. Pełka, Ł. Podstawka, T. Szymczyk, Analiza porównawcza gogli do VR, Journal of Computer Sciences Institute 10 (2019) 34-44.

[2] Wirtualna Rzeczywistość, https://systel.pl/virtualreality/, [14.10.2020].

[3] A. Kempa, T. Staś, Wstęp do programowania w C\#: Łatwy podręcznik dla, Wydawnictwo Helion, 2014

[4] Unity, https://unity.com/, [14.10.2020].

[5] Kinect with MS-SDK, https://assetstore.unity.com/packages/tools/kinectwith-ms-sdk-7747, [ 14.10.2020].

[6] Kinect, https://en.wikipedia.org/wiki/Kinect, [14.10.2020].

[7] Kinect v1 vs Kinect v2, https://www.youtube.com/watch? $\mathrm{v}=\mathrm{Zx} 2 \mathrm{E} 19 \mathrm{IV} 2 \mathrm{zs}$, [22.10.2020].

[8] Kinect v1 vs Kinect v2, https://www.youtube.com/watch?v=eNIP9nFo9n4, [22.10.2020].

[9] Comparison of Kinect v1 and v2 Depth Images in Terms of Accuracy and Precision, https://www.youtube.com/watch?v=FznorYFODCY, [22.10.2020].

[10] Kinect for Windows v1 vs v2 - Skeleton Tracking, https://www.youtube.com/watch?v=0swQqPqdd2w, [22.10.2020]. 